\title{
Pengaruh Budaya Organisasi terhadap Kinerja Dosen PTS di Provinsi Riau (Program Studi Akuntansi Dan Manajemen)
}

\author{
AFRIJAL \\ Dosen Universitas Pasir Pangaraian
}

\begin{abstract}
Lecturers are professional educators and scientists with the main task of transforming, develop and disseminate science, technology, and art through education, research, and community service. But still questioned regarding the performance of lecturers who are still not optimal, and also at private universities, especially the economic field in this case is the accounting and management still has an organizational culture that tend to be less conducive. Is this lack of conducive organizational culture influences the performance of lecturers in the works. Campus culture conducive proved a significant influence (sign value $=0.000$ ) and positive (value $\mathrm{b}=0.886$ ) on the performance of private lecturer especially those working in the accounting and management courses in Riau province. This result proves that the more conducive campus culture will increasingly meninggkat private lecturer performance.
\end{abstract}

Keywords: lecturer Performance, Organizational Culture.

\section{PENDAHULUAN}

Dosen adalah pendidik profesional dan ilmuwan dengan tugas utama mentransformasikan, mengembangkan, dan menyebarluaskan ilmu pengetahuan, teknologi, dan seni melalui pendidikan, penelitian, dan pengabdian kepada masyarakat. Profesi dosen merupakan bidang pekerjaan khusus yang dilaksanakan berdasarkan prinsip sebagai berikut: Memiliki bakat, minat, panggilan jiwa, dan idealisme; Memiliki komitmen untuk meningkatkan mutu pendidikan, keimanan, ketakwaan, dan akhlak mulia; Memiliki kualifikasi akademik dan latar belakang pendidikan sesuai dengan bidang tugas; Memiliki kompetensi yang diperlukan sesuai dengan bidang tugas; Memiliki tanggung jawab atas pelaksanaan tugas keprofesionalan; Memperoleh penghasilan yang ditentukan sesuai dengan prestasi kerja; Memiliki kesempatan untuk mengembangkan keprofesionalan secara berkelanjutan dengan belajar sepanjang hayat; Memiliki jaminan perlindungan hukum dalam melaksanakan tugas keprofesionalan; Dosen wajib memiliki kualifikasi akademik, kompetensi, sertifikat pendidik, sehat jasmani dan rohani, dan memenuhi kualifikasi lain yang dipersyaratkan satuan pendidikan tinggi tempat bertugas, serta memiliki kemampuan untuk mewujudkan tujuan pendidikan nasional. $\begin{array}{ccc}\text { Kualifikasi } & \text { akademik } & \text { yang } \\ \text { diperolehnya melalui pendidikan tinggi }\end{array}$ program pascasarjana yang terakreditasi sesuai dengan bidang keahlian, minimum: Lulusan program magister untuk program diploma atau program sarjana Lulusan program doktor untuk program pascasarjana. Sertifikat pendidik adalah bukti formal sebagai pengakuan yang diberikan kepada dosen sebagai tenaga profesional, diberikan setelah memenuhi persyaratan sebagai berikut: Memiliki pengalaman kerja sebagai pendidik pada perguruan tinggi sekurangkurangnya 2 (dua) tahun; Memiliki jabatan akademik sekurang-kurangnya asisten ahli; dan Lulus sertifikasi yang dilakukan oleh perguruan tinggi terakreditasi yang menyelenggarakan program pengadaan tenaga kependidikan pada perguruan tinggi yang ditetapkan oleh Pemerintah RI.

Untuk memperoleh sertifikasi pendidik, maka dosen tersebut harus melalui uji kompetensi yang dilakukan dalam bentuk penilaian portofolio, yaitu merupakan penilaian pengalaman akademik dan profesional dengan menggunakan portofolio dosen. Penilaian portofolio dosen dilakukan untuk menentukan pengakuan atas kemampuan profesional dosen, dalam bentuk penilaian terhadap kumpulan dokumen yang mendeskripsikan: Kualifikasi akademik dan unjuk kerja tridharma perguruan tinggi; Persepsi dari atasan, sejawat, mahasiswa dan diri sendiri tentang kepemilikan kompetensi 
pedagogik, profesional, sosial dan kepribadian; dan Pernyataan diri tentang kontribusi dosen yang bersangkutan dalam pelaksanaan dan pengembangan tridharma perguruan tinggi.

Dalam melaksanakan tugas keprofesionalan, dosen berhak: memperoleh penghasilan di atas kebutuhan hidup minimum dan jaminan kesejahteraan sosial; mendapatkan promosi dan penghargaan sesuai dengan tugas dan prestasi kerja; memperoleh perlindungan dalam melaksanakan tugas dan hak atas kekayaan intelektual; memperoleh kesempatan untuk meningkatkan kompetensi, akses sumber belajar, informasi, sarana dan prasarana pembelajaran, serta penelitian dan pengabdian kepada masyarakat; memiliki kebebasan akademik, mimbar akademik, dan otonomi keilmuan; memiliki kebebasan dalam memberikan penilaian dan menentukan kelulusan peserta didik; dan memiliki kebebasan untuk berserikat dalam organisasi profesi/organisasi profesi keilmuan.

Dalam melaksanakan

tugas

keprofesionalan, dosen berkewajiban: melaksanakan pendidikan, penelitian, dan pengabdian kepada masyarakat; merencanakan, melaksanakan proses pembelajaran, serta menilai dan mengevaluasi hasil pembelajaran; meningkatkan dan mengembangkan kualifikasi akademik dan kompetensi secara berkelanjutan sejalan dengan perkembangan ilmu pengetahuan, teknologi, dan seni; bertindak objektif dan tidak diskriminatif atas dasar pertimbangan jenis kelamin, agama, suku, ras, kondisi fisik tertentu, atau latar belakang sosioekonomi peserta didik dalam pembelajaran; menjunjung tinggi peraturan perundangundangan, hukum, dan kode etik, serta nilainilai agama dan etika; dan memelihara dan memupuk persatuan dan kesatuan bangsa. Uraian tersebut merupakan bentuk kinerja dosen dalam rangka meningkatkan mutu lulusan yang siap kerja.

Namun masih dipersoalkan mengenai kinerja dosen yang masih belum optimal dan juga pada perguruan tinggi swasta khususnya bidang ekonomi dalam hal ini adalah akuntansi dan manajemen masih memiliki budaya organisasi yang cenderung kurang kondusif. Apakah kurang kondusifnya budaya organisasi ini mempengaruhi kinerja dosen dalam bekerja.

Konsep kinerja dosen dikembangkan dari konsep kinerja secara umum. Menurut Tika (2005: 121) menyatakan kinerja sebagai hasil fungsi pekerjaan/kegiatan seseorang atau kelompok dalam suatu organisasi yang dipengaruhi oleh berbagai faktor untuk mencapai tujuan organisasi dalam periode waktu tertentu. Kemudian Lawler dan Porter dalam Sutrisno (2010: 170) menyatakan kinerja adalah kesuksesan seseorang dalam melaksanakan tugas. Kemudian menurut Miner dalam Sutrisno (2010: 170) menyatakan kinerja adalah bagaimana seseorang diharapkan dapat berfungsi dan berperilaku sesuai dengan tugas yang telah dibebankan kepadanya.

Widodo (2001: 47) bahwa kinerja adalah sesuatu yang dicapai, prestasi yang diperlihatkan dan kemampuan kerja. Kemudian menurut Mangkunegara, (2000: 67) istilah kinerja dari kata job performance atau actual performance (prestasi kerja atau prestasi, sesungguhnya yang dicapai seseorang). Pengertian kinerja adalah hasil kerja secara kualitas dan kuantitas yang dicapai oleh seseorang dalam melaksanakan tugasnya sesuai dengan tanggung jawab yang diberikan kepadanya. Selanjutnya dapat dipahami kinerja aparat mempengaruhi kinerja organisasi dimana dia berperan sebagai pelaku.

Menurut Soeprihanto (2000: 8), secara lebih rinci menyebutkan bahwa tujuan penilaian pelaksanaan pekerjaan (kinerja) sebagai berikut: 1) Mengetahui keadaan keterampilan dan kemampuan setiap pegawai secara rutin. 2) Untuk digunakan sebagai dasar perencanaan bidang personalia, khususnya penyempurnaan kondisi kerja, peningkatan mutu dan hasil kerja. 3) Dapat digunakan sebagai dasar pengembangan dan pendayagunaan pegawai seoptimal mungkin, sehingga antara lain dapat diarahkan jenjang karirnya atau perencanaan karir, kenaikan pangkat dan kenaikan jabatan. 4) Mendorong 
terjadinya hubungan timbal balik antara atasan dan bawahan. 5) Mengetahui kondisi organisasi secara keseluruhan dari bidang personalia, khususnya kinerja pegawai. 6) Secara pribadi pegawai dapat mengetahui kekuatan dan kelemahan masing-masing sehingga dapat memacu perkembangan. 7) Hasil evaluasi kinerja dapat bermanfaat bagi penelitian dan pengembangan di bidang personalia secara keseluruhan.

Peraturan Menteri Pendidikan Nasional Republik Indonesia No. 19 Tahun 2008 tentang perguruan tinggi penyelenggara sertifikasi dosen, dan Peraturan No. 20 Tahun 2008 tentang penetapan in passing pangkat dosen bukan pegawai negeri sipil yang telah menduduki jabatan akademik pada perguruan tinggi yang diselenggarakan oleh masyarakat dengan pangkat pegawai negeri sipil, telah membuat gairah para dosen khususnya di lingkungan perguruan tinggi swasta untuk memulai memperhatikan jenjang akademiknya. Karena jenjang akademik adalah merupakan salah satu bentuk penilaian pemerintah atas kinerja seorang dosen.

Bagi suatu perguruan tinggi, salah satu pihak yang berperan strategis dalam meningkatkan kemajuan dan kualitas lembaga tersebut adalah kinerja dosen (lecturer). Sejalan dengan pernyataan tersebut Khoe Yao Tung dalam Achmad Sanusi dan Sanusi Uwes dalam Muhardi (2004), menyatakan bahwa "Dosen merupakan faktor kunci sukses (key success factor) dari upaya untuk meningkatkan mutu jasa pendidikan". Pendapat yang sama dikemukakan oleh Abdurrachman dan S. Marten Yogaswara dalam Muhardi (2004:34) bahwa "Nilai keberhasilan pendidikan sangat tergantung dari mutu pengajarnya. Dosen adalah orang yang sangat berperan dalam proses belajar mengajarnya".

Dosen harus mempunyai beberapa kualifikasi yang diperlukan bagi pelaksanaan profesinya, mengingat profesi dosen berbeda dengan profesi bidang yang lain. Selain memerlukan ilmu pengetahuan juga harus menyampaikan ilmunya kepada mahasiswa. Dengan tenaga dosen yang mempunyai motivasi, berkompeten dan berkualitas akan memudahkan penyampaian ilmu pengetahuan dan teknologi sehingga apa yang disampaikan kepada mahasiswa dapat diterima dan dikembangkan sesuai dengan kemampuan mahasiswa dengan kajian bidang ilmu yang dipilihnya. Di samping itu dosen juga harus mempunyai komitmen yang tinggi yang ditunjukkan dengan kehadiran pada waktu kerja, juga mempunyai rasa tanggung jawab terhadap ilmu yang diberikan kepada mahasiswa.

Untuk mengetahui tinggi rendahnya kinerja dosen dalam melakukan pekerjaannya maka diperlukan adanya system penilaian terhadap kinerja dosen. Penilaian kinerja adalah suatu cara yang digunakan untuk mengukur pekerjaan yang dilakukan sesuai dengan target yang telah ditetapkan.

Sebagai tenaga professional, dosen yang bekerja dan menjalankan tugasnya, profesi juga perlakukan dilakukan penilaian dalam menjalankan pekerjaannya sebagai pendidik. Pentingnya penilaian kinerja dosen juga dikemukakan oleh Aiken Lewis R dalam Umi Narimawati (2005) "Bahwa penilaian terhadap kinerja dosen penting/ perlu dilakukan, mengingat dosen dalam posisi penting dalam mempengaruhi pelaksanaan pendidikan mahasiswanya maka tidak mengherankan apabila pemerintah, orang tua mahasiswa, serta yang lain memeprhatikan mutu pendidikan melalui kemampuan seorang dosen".

Menurut Ridwan (2011: 191) kinerja dosen adalah kualitas hasil kerja yang dilakukan dosen dalam pengajaran (proses belajar mengajar). Kesimpulan ini didasarkan pada konsep bahwa kinerja dosen adalah seperangkat perilaku yang ditunjukkan oleh dosen pada saat menjalankan tugas dan kewajibannya dalam bidang pengajaran dengan dimensi: kemampuan, prakarsa/inisiatif, ketepatan waktu, kualitas hasil kerja dan komunikasi.

Kemudian Ridwan (2011: 216) juga menjelaskan mengenai uraian dari masingmasing dimensi sebagai berikut:

a. Kemampuan yakni penguasaan materi dan penguasaan metode pengajaran. 
b. Inisitif yakni berpikir positif yang lebih baik dan mewujudkan kreatifitas dan pencapaian prestasi.

c. Ketepatan waktu yakni pemanfaatan waktua kedatangan dan pemanfaatan waktu pulang.

d. Kualitas hasil kerja yakni kepuasan mahasiswa dan pemahaman mahasiswa serta prestasi mahasiswa.

e. Komunikasi yakni mutu penyampaian dan juga penguasaan keadaan kelas.

Sehubungan dengan penilaian kinerja, Craigh dalam umi Narimawati (2005) mengidentifikasi sumber - sumber masalah dalam penilaian kinerja, yaitu; (a) competency problem, (b) motivational problem, dan (c) leadership and organizational problem. Dengan demikian kinerja seseorang sangat dipengaruhi oleh kompetensi yang dimiliki oleh setiap individu yang dilakukan evaluasi. Motivasi seseorang dalam melakukan tugas serta gaya kepemimpinan yang berlaku, aturan, dan lingkungann dari suatu organiasi tempat seseorang bekerja.

Berdasarkan pendapat tersebut di atas, jelas dapat dikatakan bahwa kinerja adalah suatu kumpulan total dari perilaku kerja yang ada pada pekerja, dalam kaitannya dengan kinerja dosen yaitu perilaku kerja dosen yakni dalam melaksanakan tri dharma perguruan tinggi yakni pengajaran, penelitian dan pengadian masyarakat.

Menurut Robins (2001 : 273), bahwa: "Sejumlah faktor struktural menunjukkan suatu hubungan ke kinerja. Di antara faktor yang lebih menonjol adalah persepsi peran, norma, inekuitas status, ukuran kelompok, susunan demografinya, tugas kelompok dan kekohesifan (saling terkait)". Sedangkan menurut Mangkunegara (2002: 67) mengatakan bahwa faktor-faktor yang mempengaruhi kinerja pegawai adalah: 1) Faktor kemampuan dan 2) Faktor motivasi.

Kemudian faktor-faktor yang mempengaruhi kinerja pegawai, secara rinci dikemukakan oleh Mangkunegara (2002: 67) menyatakan bahwa setiap usaha untuk mengetahui mengapa seseorang berprilaku seperti yang dilakukan selama ini dalam organisasi memerlukan pemahaman tentang:
(1) individu yang memiliki kemampuan, keterampilan mencakup mental dan fisik, latar belakang: keluarga, umur dan jenis kelamin, (2) organisasi meliputi : sumber daya, kepemimpinan, imbalan dan prosedur kerja, tim work dan (3) psikologi meliputi: persepsi, sikap, kepribadian dan motivasi serta komitmen. Lebih dari itu, adapun yang mempengaruhi faktor-faktor kinerja dalam suatu organisasi adalah faktor kemampuan dan faktor motivasi.

Berdasarkan uraian tersebut, maka dapat disimpulkan bahwa kinerja dosen adalah kualitas hasil kerja yang dilakukan dosen dalam pengajaran (proses belajar mengajar) dan juga sebagai seperangkat perilaku yang ditunjukkan oleh dosen pada saat menjalankan tugas dan kewajibannya dalam bidang pengajaran dengan dimensi: kemampuan, prakarsa/inisiatif, ketepatan waktu, kualitas hasil kerja dan komunikasi. Uraian dari masing-masing dimensi sebagai berikut:

a. Kemampuan yakni penguasaan materi dan penguasaan metode pengajaran.

b. Inisitif yakni berpikir positif yang lebih baik dan mewujudkan kreatifitas dan pencapaian prestasi.

c. Ketepatan waktu yakni pemanfaatan waktua kedatangan dan pemanfaatan waktu pulang.

d. Kualitas hasil kerja yakni kepuasan mahasiswa dan pemahaman mahasiswa serta prestasi mahasiswa.

e. Komunikasi yakni mutu penyampaian dan juga penguasaan keadaan kelas.

Selain itu berkaitan dengan konsep budaya organisasi dikembangkan menurut Ndraha (2005: 74) mengatakan budaya organisasi merupakan gaya dan cara hidup organisasi sebagai pencerminan dari nilainilai atau kepercayaan yang selama ini dianut oleh seluruh anggota organisasi. Juga merupakan pola kepercayaan, nilai ritual, mitos para anggota suatu organisasi yang mempengaruhi perilaku semua individu dan kelompok di dalam organisasi. Termasuk juga aktivitas budaya organisasi mempengaruhi kehidupan organisasi seperti 
bagaimana keputusan dibuat, siapa yang membuatnya, bagaimana imbalan dibagikan, bagaimana orang diperlakukan dan bagaimana organisasi memberi respon kepada lingkungannya, dan lain-lain.

Menurut Martani (2009: 4) bahwa organisasi sebagai suatu kesatuan sosial dari sekelompok individu (orang), yang saling berinteraksi menurut suatu pola yang terstruktur dengan cara tertentu sehingga setiap anggota organisasi mempunyai tugas dan fungsinya masing-masing dan sebagai suatu kesatuan mempunyai tujuan tertentu, dan juga mempunyai batas-batas yang jelas, sehingga organisasi dapat dipisahkan secara tegas dari lingkungannya. Lebih lanjut Thoha (2008: 1117) menjelaskan organisasi sebagai kolektifitas orang-orang yang bekerjasama secara sadar dan sengaja untuk mencapai tujuan tertentu.

Sedangkan menurut Chatab (2007: 10) dijelaskan bahwa budaya organisasi adalah pengendali sosial dan pengatur jalannya organisasi atas dasar nilai dan keyakinan yang dianut bersama, sehingga menjadi norma kerja kelompok dan secara operasional disebut budaya kerja karena merupakan pedoman dan arah perilaku kerja karyawan. Lebih lanjut dijelaskan bahwa fungsi budaya organisasi adalah sebagai identitas, pemersatu, sumber inspirasi, sumber penggerak, kemampuan meningkatkan nilai tambah, pengganti formalisasi, mekanisme adaptasi dan orientasi.

Berdasarkan beberapa pendapat mengenai budaya organisasi tersebut, maka dapat disimpulkan budaya organisasi adalah sebagai gaya dan cara hidup organisasi sebagai pencerminan dari nilai-nilai atau kepercayaan yang selama ini dianut oleh seluruh anggota organisasi dalam mencapai tujuannya.

Menurut Robbins dalam Chatab (2007: 27) terdapat 7 (tujuh) dimensi budaya organisasi, antara lain: 1) Inovasi dan pengambilan resiko, yaitu tingkat seberapa jauh para anggota organisasi didorong menjadi inovatif dan pengambilan resiko guna mewujudkan visi; 2) Perhatian pada detail, yaitu tingkat seberapa jauh para anggota organisasi diharapkan untuk memperlihatkan presisi, analisis dan perhatian untuk detail; 3) Orientasi hasil, yaitu tingkat seberapa jauh manajemen fokus pada hasil dari pada teknik dan proses yang dipakai untuk mencapai hasil-hasilnya; 4) Orientasi kepada para individu, yaitu tingkat seberapa jauh keputusan manajemen memperhitungkan dampaknya pada para individu dalam organisasi; 5) Orientasi tim, yaitu tingkat seberapa jauh aktivitas pekerjaan diorganisasikan kepada tim daripada individual; 6) Keagresifan, yaitu tingkat seberapa jauh para individu agresif dan kompetitif daripada easy going; dan 7) Stabilitas, yaitu tingkat sejauhmana kegiatan organisasi menekankan posisi status quo daripada perubahan organisasi.

Kemudian dijelaskan budaya perguruan tinggi menurut Ariftianto (2013: 2) adalah sikap hidup yang selalu mencari kebenaran ilmiah melalui kegiatan akademik dalam masyarakat akademik, yang mengembangkan kebebasan berpikir, keterbukaan, pikiran kritis-analitis; rasional dan obyektif oleh warga masyarakat akademik" Konsep dan pengertian tentang Budaya Akademik tersebut didukung perumusan karakteristik perkembangannya yang disebut. Dimensi budaya perguruan tinggi antara lain penghargaan terhadap pendapat orang lain secara obyektif, kemudian pemikiran rasional dan kritisanalitis dengan tanggungjawab moral, selanjutnya kebiasaan membaca dan penambahan ilmu dan wawasan kemudian kebiasaan meneliti dan mengabdi kepada masyarakat serta penulisan artikel, makalah, buku; diskusi ilmiah dan proses belajarmengajar serta Manajemen perguruan tinggi yang baik.

Budaya organisasi adalah sebagai gaya dan cara hidup organisasi sebagai pencerminan dari nilai-nilai atau kepercayaan yang selama ini dianut oleh seluruh anggota organisasi dalam mencapai tujuannya. Dimensi dari budaya organisasi berupa:

a. Menghargai pendapat orang lain yakni penghargaan terhadap pendapat orang lain secara obyektif 
b. Pemikiran rasional dan kritis-analitis dengan tanggungjawab moral

c. Kebiasaan membaca yakni dalam rangka menambah pengetahuan

d. Penambahan ilmu dan wawasan

e. Kebiasaan meneliti dan mengabdi kepada masyarakat

f. Penulisan artikel, makalah, buku.

g. Diskusi ilmiah

h. Proses belajar-mengajar

i. Manajemen perguruan tinggi yang baik

Hasil kajian Ambarita,

menjelaskan bahwa ada pengaruh langsung yang positif dari budaya organisasi terhadap kinerja kuliah, ada pengaruh langsung yang positif dari budaya organisasi terhadap kepuasan kerja, terdapat pengaruh langsung positif budaya organisasi terhadap komitmen organisasi. Kemudian juga hasil kajian Ari Cahyono, 2012, bahwa variabel Budaya Organisasi berpengaruh signifikan terhadap kinerja dosen dan karyawan, dengan t hitung 2,882 lebih besar dari t tabel 1,980 dan nilai Sig 0,005 lebih kecil dari 0,05.

\section{METODE}

Metode penelitian yang digunakan adalah metode kuantitatif. Populasi dalam penelitian ini adalah seluruh dosen di Universitas Swasta pada tiga perguruan tinggi diambil sampel sebanyak 68 orang. Teknik pengambilan sampel dengan menggunakan teknik sampling jenuh. Teknik pengumpulan data dilakukan dengan cara penelitian lapangan dan studi kepustakaan. Data penelitian dianalisis dengan menggunakan teknik analisa regresi linier sederhana.

\section{HASIL}

Kinerja dosen adalah seperangkat perilaku yang ditunjukkan oleh dosen pada saat menjalankan tugas dan kewajibannya dalam bidang pengajaran dengan dimensi: kemampuan, prakarsa/inisiatif, ketepatan waktu, kualitas hasil kerja dan komunikasi diketahui bahwa kinerja dosen Prodi Manajemen dan Akuntansi dengan skor 3,04 atau $60,9 \%$ masuk dalam kategori cukup baik. Kemudian variabel budaya organisasi yang sikap hidup yang selalu mencari kebenaran ilmiah melalui kegiatan akademik dalam masyarakat akademik, yang mengembangkan kebebasan berpikir, keterbukaan, pikiran kritis-analitis; rasional dan obyektif oleh warga masyarakat akademik juga diketahui bahwa budaya organisasi dengan skor 3.42 atau $68.4 \%$ masuk dalam kategori cukup baik.

Berdasarkan hasil pengolahan data variabel kinerja dosen dengan budaya organisasi diperoleh informasi sebagai berikut:

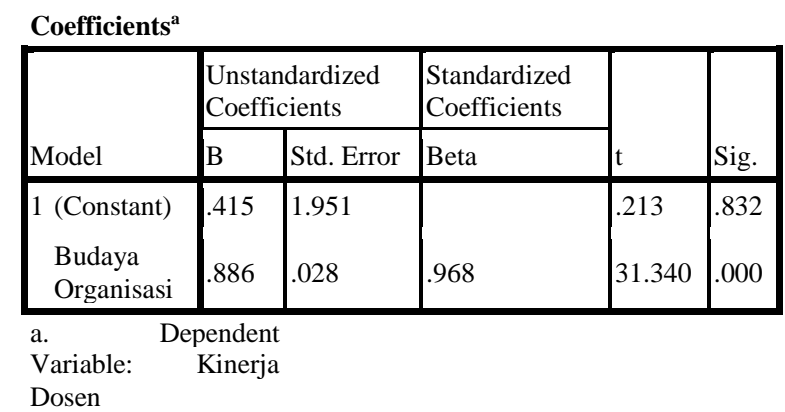

Dari data tersebut menjelaskan bahwa formulasi dari persamaan regresi yang diperoleh berkaitan dengan konsep variabel kinerja dan budaya organisasi sebagai berikut:

$\mathrm{Y}=0,415+0,886 \mathrm{X}$

Kemudian

Nilai t hitung sebesar 31,340 dengan sign 0,000

Temuan tersebut memberikan makna bahwa nilai konstanta sebesar 0,415 menunjukkan bahwa nilai kinerja dosen pada saat budaya organisasi tidak ada yakni sebesar 0,415. Kemudian nilai koefisien regresi untuk variabel $\mathrm{X}$ (budaya organisasi) sebesar 0,886 ini berarti bahwa budaya organisasi memberikan pengaruh positif terhadap kinerja dosen. Maksudnya adalah semakin mendukung budaya organisasi dalam hal ini adalah budaya kampus, maka akan semakin tinggi kinerja dosen dalam bekerja. Begitu pula sebaliknya, semakin rendah dukungan budaya kampus maka kinerja dosen akan menurun.

Hasil uji hipotesis statistik juga menunjukkan bahwa dengan nilai sign 0,000 
menunjukkan bahwa variabel budaya organisasi memiliki nilai sign lebih kecil dibandingkan dengan standar atau alpha 0,05. Hal ini membuktikan bahwa budaya organisasi memberikan pengaruh signifikan terhadap kinerja dosen pada program studi akuntansi dan manajemen di Propinsi Riau.

\section{PEMBAHASAN}

Berdasarkan hasil perhitungan menunjukan bahwa budaya organisasi berpengaruh positif dan signifikan terhadap kinerja dosen. Besar kecilnya kontribusi budaya organisasi berdasarkan hasil perhitungan diperoleh nilai korelasi korelasi variabel budaya organisasi (X) terhadap variabel kinerja dosen (Y) adalah sebesar 0,886 . Hal ini menunjukkan hubungan yang kuat antara budaya organisasi dengan kinerja dosen. Sedangkan besarnya pengaruh budaya organisasi terhadap kinerja dosen ditunjukkan dengan koefisien regresi sebesar 0,415, artinya kenaikan nilai dari variabel kepemimpinan dan kompensasi, maka setiap kenaikan nilai budaya organisasi satu satuan, maka nilai budaya organisasi bertambah sebesar 0,415, karena pengaruh positif. Pengaruh variabel budaya organisasi ini juga signifikan karena angka sig sebesar 0,000 atau lebih kecil dari 0,05.

Pengaruh budaya organisasi terhadap kinerja dosen berkaitan dengan sikap hidup yang selalu mencari kebenaran ilmiah melalui kegiatan akademik dalam masyarakat akademik, yang mengembangkan kebebasan berpikir, keterbukaan, pikiran kritis-analitis; rasional dan obyektif oleh warga masyarakat akademik. Penghargaan terhadap pendapat orang lain secara obyektif; pemikiran rasional dan kritis-analitis dengan tanggungjawab moral; kebiasaan membaca; penambahan ilmu dan wawasan; kebiasaan meneliti dan mengabdi kepada masyarakat; penulisan artikel, makalah, buku; diskusi ilmiah; proses belajar-mengajar, Manajemen perguruan tinggi yang baik.

Kampus cukup menghargai pendapat dengan diiringi bukti, cukup menghargai saran dengan solusi dan hal ini berpengaruh terhadap insiatif dosen dalam melaksanakan tugasnya di lapangan. Kritik dan saran yang diberikan dalam rangka membangun sangat membuat dosen berpikir positif dalam mewujudkan kreatifitas pencapaian prestasi.

Masyarakat kampus cukup memiliki pemikiran rasional dan kritis-analitis dengan tanggungjawab moral sehingga kualitas hasil kerja sebagai indikator kinerja dapat lebih baik.

Masih rendahnya kebiasaan membaca dari kalangan dosen sehingga kualitas hasil kerja dari warga kampus kurang meningkat sehingga kepuasan mahasiswa, pemahaman mahasiswa dan prestasi mahasiswa dalam pembelajaran ikut terpengauh.

Warga kampus cukup selalu menambah ilmu dan wawasan hal ini berdampak terhadap peningkatan kemampuan dosen dalam rangka mengembangkan ilmu pengetahuan.

Warga kampus cukup memiliki kebiasaan meneliti dan mengabdi kepada masyarakat sehingga terjalin komunikasi dengan pihak yang berkepentingan terhadap perguruan tinggi dalam hal ini adalah masyarakat.

Kampus cukup selalu melakukan penulisan artikel, makalah, buku sehingga dosen dituntut untuk selalu meningkatkan kualitas hasil kerja dari waktu ke waktunya.

Kampus cukup selalu melaksanakan diskusi ilmiah sehingga dosen dapat meningkatkan kemampuan dalam melaksanakan tugasnya yakni tri dharma perguruan tinggi.

Kampus cukup selalu melaksanakan proses belajar-mengajar sehingga kualitas hasil kerja dalam rangka memuaskan mahasiswa dan memberikan pemahaman serta meningkatkan prestasi mahasiswa ikut terpengaruh.

Manajemen perguruan tinggi selalu melaksanakan pengelolaan kegiatan kampus sehingga komunikasi selalu terjalin dengan warga kampus dan dosen dapat meningkatkan kinerjanya.

Hasil penelitian tersebut di atas jelas menunjukkan bahwa budaya organisasi berpengaruh signifikan kinerja dosen. Hasil 
penelitian ini tidak jauh berbeda dengan pendapat Ari Cahyono (2012) variabel budaya organisasi berpengaruh signifikan terhadap kinerja dosen dan karyawan, dengan t hitung 2,882 lebih besar dari t tabel 1,980 dan nilai Sig 0,005 lebih kecil dari 0,05.

\section{SIMPULAN}

Dari uraian di atas, maka dapat disimpulkan bahwa terbukti budaya kampus yang kondusif memberikan pengaruh yang signifikan dan positif terhadap kinerja dosen swasta khususnya yang bekerja pada program studi akuntansi dan manajemen di propinsi Riau. Hasil ini membuktikan bahwa semakin kondusif budaya kampus maka akan semakin meninggkat kinerja dosen swasta.

\section{DAFTAR PUSTAKA}

Mangkunegara, 2002, Manajemen Sumber Daya Manusia Perusahaan., PT. Remaja Rosdakarya, Bandung.

Muhardi, 2004, Pengaruh Pemasaran Internal Terhadap Kepuasan Dosen Tetap dan Komitmennya Pada Mutu Jasa Pendidikan, Serta Implikasinya Terhadap Mutu Layanan Kepada Mahasiswa

Ndraha, 2010, Teori Budaya Organisasi. Rhineka Cipta, Jakarta.

Pabundu Tika, 2010, Budaya Organisasi dan Peningkatan Kinerja Perusahaan, Bumi Aksara, Jakarta.

Pamudji, 2005, Kepemimpinan Pemerintahan Indonesia, Jakarta: Bumi Aksara.

Pangabean, 2004, Manajemen Sumber Daya Manusia. Galia Indonesia, Bogor

Peraturan Menteri Pendidikan Nasional Republik Indonesia No. 19 Tahun 2008 tentang perguruan tinggi penyelenggara sertifikasi dosen
Peraturan No. 20 Tahun 2008 tentang penetapan in passing pangkat dosen bukan pegawai negeri sipil

Ridwan, 2011, Cara Menggunakan dan Memaknai Path Analysis, Alphabeta, Bandung

Robbins, 2008, Perilaku Organisasi, Terjemahan Tim Indeks. Indeks Garamedia, Jakarta.

Siagian, 2008, Manajemen Sumber Daya Manusia, Bumi Aksara, Jakarta.

Soeprihanto, 2000, Responsivitas dan Akuntabilitas Sektor Publik, Dalam Jurnal Administrasi Negara (Volume 1 No. 2 Maret 2001), FIA Unibraw, Malang.

Sutrisno, 2010, Budaya Organisasi, Kencana Prenada Media Group, Jakarta.

Tika, 2005, Budaya Organisasi dan Peningkatan Kinerja Perusahaan, Bumi Aksara, Jakarta.

Umi Narimawati, 2005, Pengaruh Kecocokan Kerja, Kepuasan Kerja, dan Komitmen Organisasional Terhadap Intensi Keluar Dosen dan Kinerja Dosen 